\title{
Stewardship, Transformational Change, and Regime Shifts in the Arctic
}

Arctic stewardship was the main theme of almost 30 presentations given at the science session of the Arctic Frontiers Conference organized in Tromsø, Norway, in January 2016. Stewardship is an essential element of long-term, viable, peopleenvironment relationships, reflecting the fact that humans and the rest of nature are mutually interdependent. As the Arctic region is emerging as a global crossroads between public interest and private and commercial gain, the session set out to discuss different aspects of stewardship such as public and private stewardship. In addition to discussing stewardship, contributions included Arctic narratives and presentations on the Arctic as part of the global environment. Our perceptions of the Arctic affect various aspects of human organization and activity in the region - in law and politics, as well as civil and corporate society.

Conference presentations on the Arctic as part of the global environment included investigations of how other regional and global regimes and drivers affect the stewardship of the region. This issue of the Arctic Review on Law and Politics includes three articles based on presentations given at Arctic Frontiers in January 2016.

Dorottya Bognar, in her article, examines the role and contributions of the Russian Federation, a major Arctic coastal state, to negotiations on the Polar Code through the International Maritime Organization. She examines and assesses how Russian interests influenced positions taken.

Daria Shapovalova sets out to investigate measures taken at the regional level to reduce emissions of black carbon, the second largest cause of the warming of the Arctic. She examines and assesses soft law and hard law approaches to mitigation.

Ilan Kelman, Julia S.P. Loe, Elana Wilson Rowe, Emma Wilson, Nina Poussenkova, Elena Nikitina, and Daniel Buikema Fjertoft investigate how corporate social responsibility (CSR) - controversial in petroleum exploration and exploitation - is perceived at the local level, through interviews with people in four different Arctic locations. CSR can be described as private stewardship, and in the article, the authors emphasize the importance of understanding complex, interacting contexts within any community to reach the goals of CSR.

In addition to articles arising from the Arctic Frontiers Conference, we are pleased to present an article that analyzes the rapidly changing Arctic. 
Annika E. Nilsson and Timo Koivurova analyze transformational change in the circumpolar Arctic as a potential case of a regime shift in a large-scale socialecological system with focus on governance structures. The authors argue that particular focus should be placed on political processes and governance structures, as these play important roles in social negotiations on the relationship between societies and the environment.

This issue also includes an analysis of a recent Supreme Court decision in Norway on a dispute over title rights between Sámi reindeer herders and Finnmark Estate, which contains an interesting assessment of ILO 169's bearing on the Finnmark Act. In addition, we have the pleasure of presenting a book review of a Russian monography on indigenous people's rights, as well as excerpts from UN Secretary General Ban Ki-moon's speech at the Arctic Circle Assembly in Reykjavik after he received the 2016 Arctic Circle Prize for his key role in the success of the Paris Climate negotiations.

Tore Henriksen

Guest Editor

Oyvind Ravna

Editor-in-Chief 